IIUC STUDIES

ISSN 1813-7733

Vol.- 9, December 2011

(p 187-214)

\title{
Accounting in Islamic Perspective: A Timely Opportunity, a Timely Challenge
}

\author{
Dr. Alim Al Ayub Ahmed Arif Billah* \\ Md Alidul Islam ${ }^{* *}$
}

\begin{abstract}
Accounting from Islamic Perspectives (AIP) is an emerging field. Recent years have attracted scholars from around the world who have contributed their thoughts about how accounting can be seen from the Islamic lens. However, the efforts so far are rather fragmented and without a clear agenda for future research. This paper presents a review of the literary achievements made in the field and the areas of current focus. Although the field carries a huge growth potential, the author argues that there are several challenges and problems that the proponents of AIP will face as the field develops further. This paper outlines these problems and challenges and makes suggestions to surmount the potential pitfalls. It is argued herein that, in order to develop AIP as a formal discipline and integrate it within real-life business practices, the research efforts need to be more organized through an international consortium of researchers. A brief proposal for such consortium is included here. Finally, recommendations are made for potential research directions in which future research on AIP can be pursued.
\end{abstract}

Keywords: Accounting, Islamic Perspective, Business, Organizations

\section{Introduction}

Islamic world has been lagging behind in contributing towards scientific and technological advancement. There is reality in the truth as statistics show that the Muslim world has so far produced only two Nobel Laureates; there are only two universities in the Islamic world

\footnotetext{
* ASA University

${ }^{* *}$ Reader, Innovation in Marketing and Accounting
} 
that are ranked among top 500 universities of the world; there are less than 600 universities in the member Islamic states of Organization of Islamic Countries; and 41 predominantly Muslim countries- that constitute $20 \%$ population of the world-produce less than $5 \%$ of the science (see: Segal, 1996; and Schopper, 2006). Segal (1996) lamented that the Islamic world produces a disproportionately small amount of scientific output, which is relatively very low in quality. This is an alarming situation. However, there seems some light in the end of the tunnel. Currently, there are many attempts underway to improve the situation in various academic disciplines where Muslims are coming upfront to contribute to various knowledge domains, sometimes from specific Islamic perspective. Accounting from Islamic Perspectives (AIP) is one such knowledge domain, which has recently attracted many Muslim scholars to pay a serious attention.

Conventional accounting is a well-established field; although there is no doubt that a major contribution to the extant body of knowledge on accounting comes from the West rather than the East. Most theories and frameworks in contemporary body of knowledge on accounting come from the West without any reference to practices in the East. Also, most Western perspectives on 'accounting' are predominantly secular and capitalistic in nature. Such underlying convictions of contemporary accounting theories have resulted in growing incoherence within Eastern societies, which are more religious and socialistic. On the other hand, there is much less contribution from the East, particularly from the Muslim world. Moreover, there is an obvious scarcity of literature on Islamic viewpoint on management (Kazmi, 2003; Ismail and Sarif, 2007). At individual or small group level, the work on accounting from Islamic viewpoint can be traced back to authors such as Bani-Sadr (1980), Ezzati (1982), Fariduddin, Sharfuddin (1987), Shirazi (1988/1408), Chapra (1992), Rahman and AI-Buraey (1992), Faridi (1995), Beekun (1997), Beekun and Badawi (1998), Al-Buraey (2003), Kazmi (2003); and more recently, Ather (2005), Abuznaid (2006) and Beekun (2006), and Ata al-Sid (2007), who have explored the field of accounting in a direct or indirect relation to Islamic teachings. In addition to these works, some rare $\mathrm{PhD}$ dissertations that address management from Islamic perspectives include the works of Gahein (1986), Khalifa (2001) and Mohiuddin (2004). At relative large scale, some notable endeavors to explore management from Islamic lens include a Seminar on Islamic Management held by IRTI (Islamic Research and Training Institute) in 
Malaysia in 1987 and International Conference on Management from Islamic perspectives (ICMIP) in 2007.

A recent exploratory study of Sobhani and Ather (2007) has shown that the development and practices of Islamic Management in Bangladesh, a predominantly Muslim country, is very insignificant and incommensurate to the population and that the concept of Islamic Management in largely unknown. On the other hand, conventional accounting practices are widely known and practiced. This example shows that AIP is not even a commonly known discipline in the Islamic societies. Though some organizations would like to claim that their accounting practices follow the Islamic principles, such claims are without an explicit recognition of AIP as an established set of principles driving the everyday life of such organizations.

However, with spreading awareness about important role that different cultural norms, language, spirituality, religiosity, social values, literary expressions and symbolic modes play in the business environment, researchers are diverting their focus on understanding the businesses in an entirely different way. This movement is called postmodernism and it accepts the possibility that several theories, which can conflict, can still have a legitimate place in a social discourse (Goulding, 2003). Under the influence of postmodernism and more importantly, a soaring interest in Islamic banking and finance around the world has opened the doors for Muslim scholars to think how other disciplines of accounting can complement the developments in Islamic economic systems. Toor (2007) observes that the spreading awareness about Islam, escalating demand for management in Islamic way, growing focus on Islamic banking systems, emerging concept of Shariah compliance, evolving notion of dispute resolution in Islamic way, and prolific wave of Islamic revival are some factors that have gradually accentuated a need for formulation, testing, and validation of the Islamic leadership construct, and steadily integrate it within Islamic management practices. There have been debates and discussions in the literary circles around the world, particularly in the Islamic nations, as to how accounting can be viewed from the lens of Islamic teachings, and how modern accounting practices can be transformed to synchronize with Islamic philosophy of life.

This paper is a review of the extant body of knowledge on accounting from Islamic perspectives. It draws attention to certain issues with the hope that any further initiatives in the field effectively contribute to the 
development and growth of AIP as a formal discipline. The author develops the case to argue that AIP scholars must be cognizant of the history of the field, motives that are driving the development of the field, contemporary issues that need priority attention in terms of research, directions in which the future research can be directed, and issues and challenges that are likely to emerge in developing AIP as a formal discipline that is likely to result in the emergence of "Islamic Accounting Theory" in the future. The field is still at a nascent stage and is developing gradually. As research in this area grows further, the existing body of knowledge will mature, new sub-disciplines will emerge and the field will grow. However, for sustainable development of AIP as a discipline, researchers need to take adequate steps to avoid potential pitfalls and problems that can hinder the growth of the field after it has gained certain momentum. Recommendations made in this paper are with to initiate a dialogue to highlight more potential issues, problems, challenges, areas of general focus, areas of priority, and areas of caution. Discussion in this paper is very timely, given the field is emerging rapidly and the future potential is very promising.

\section{Why Accounting from Islamic Perspectives?}

Describing the challenges of modern business enterprises, Professor William George (2003) at Harvard observes that measures of business development such as growth, cash flow, and return on investment are fading away, and new criterion of success is "meeting the expectations of security analysis". To reach the earning targets, investments are cut back resulting in the growth potential of company. To achieve the targets, investments are cut back resulting in the growth potential of company. To achieve the targets of profit maximization and to satisfy shareholders, CEOs go to extreme measures. They have become forgetful of human and social capitals, which earn long-term success for the companies. They are anxious about profit maximization at the expense of their employees and organizational values. Businesses of today are undoubtedly going through a tumultuous era and markets are more challenging than ever before. Such situation is no less than a management and accounting crisis in the contemporary business world, which is built on the model of capitalism. Apparent divorce of spirituality from workplace is due to implicit or explicit assumption those workplaces or other social institutions are secular (Hicks, 2002) and secularism attempted to keep religion a personal matter. George even goes to saying that capitalism has become the victim of it own success. Modern organizations seem to suffer from so-called "management crisis" due to every day corporate scandals, where leaders 
betray their own people and strive for worldly benefits. They are only concerned about shareholders' satisfaction and forget about their other moral and ethical obligations to their organizations, followers, and society at large. This leads to every materialistic approach to management and accounting in the secularist and capitalistic systems, which have successfully penetrated the many Islamic societies as well. This is largely due to the curriculum of the schools and universities in the Muslim countries that teaches various modern European arts and sciences, which are far the most part alien to the Islamic perspective, has to a large degree injected an element of secularism into the mind of fairly sizeable segment of Islamic society (Nasr, 1961, cited in Ataal Sid, 2007). However, Yom (2002) argues that secularism is increasingly less relevant in the globalizing world, where religious identities have strengthened and believers have grows in perpetuating and sharing their narrative visions of the past, present, and future. Weary of the secular models, a widening circle of scholars is now considering religion as a viable alternative (Rae and Wong, 1996). In this respect, accounting from Islamic perspectives is more relevant.

Abuznaid (2006) argues that though Islam does not provide a comprehensive theory in accounting, nevertheless, it does provide set of general guidelines that can be applied to achieve the fundamental goals of management that are not fundamentally materialist (Rice, 1999). Primary goals of Islam are based on the concept of human well being and good life, which stress brotherhood/ sisterhood and socioeconomic justice, and require a balanced satisfaction of both the material and spiritual needs of all humans (Chapra, 1992). In the Islamic ethical system, specific guidelines are available for achieving the moral filter and for conducting business. (Toor, 2007) also observes "Islam provides the most comprehensive understanding of leadership through its highly developed and modern ethical system that seeks guidelines from Quran, Sunnah, and sayings of Prophet Muhammad [PBUH]" (Toor, 2007, pp. 1). Others also note that Islam provides comprehensive guidelines in all facets of life-be it religious, moral, ethical, social-cultural, economic, political, or legal-to underpin the foundations of a strong Islamic society, which is built upon complete submission to Allah and teachings of Prophet Muhammad (PBUH)” (Toor, 2007; Beik and Arsyianti, 2007).

In this respect, spirituality and religion in Islam are not two separate entities; they are rather branches of the same tree. Scholars have argued that many of the characteristics of spirituality in the workplace 
are basis themes of Islam. These characteristics may include the building of community, concern for social justice within the organization and its vision, and equality of voice (see Kriger and Seng, 2005). "The values of service, surrendering self, truth, charity, humility, forgiveness, compassion, thankfulness, love, courage, faith, kindness, patience, and hope, in the workplace spirituality literature (see Fry, 2003) are to be found not only in the Quran, but also in popular Islamic wisdom literature, philosophical debates and the mystical guidance of esoteric Islam, Sufism” (Kriger and Seng, 2005).

From Islamic perspectives, therefore, accounting is all about practicing the positive norms and bringing self-transcendent values in everyday life, while seeking the will of God and following his orders in form of Prophet's (PBUH) Sunnah. Goals of Islamic accounting and management are not merely worldly and money-oriented; rather they endeavor to seek a long-term intrinsic reward, the pleasure of God. Islam holds all leasers and followers responsible for societal building and for spreading the rule of Allah on earth. Both sides are equal in the eyes of Allah and hence should perform their roles with greatest integrity and dedication.

Under such a accounting system, where only positive organizational behaviors are encouraged and performed in everyday life, there is high chance that a positive organizational scholarship (see Cameron et al., 2003) can be obtained where "organizations are typified by appreciation, collaboration, virtuousness, vitality and meaningfulness. Creating abundance and human well-bring are key indicators of success...members of such organizations are characterized by trustworthiness, resilience, wisdom, humility, and high levels of positive energy...social relationships and interactions are characterized by compassion, loyalty, honesty, respect, and forgiveness. Significant attention is given to what makes life worth living." In the above vision, which Professor Kim Cameron has presented in his book: "Positive Organizational Scholarship", is fully in line with what the current paper discusses as "Accounting from Islamic Perspectives”.

\section{Literary Achievements}

The author has argued in the previous pages that AIP is an emerging field. However, very recent endeavors in the area have focused on diverse subjects. Particularly, the International Conference on Management from Islamic Perspectives (ICMIP) has been able to attract rich perspectives from around the world resulting in a 
significant volume of works on various subjects within the domain of AIP. Though a large body of knowledge exists on Islamic banking and Islamic finance, literary attempts have been made in other directions including, but not limited to, concept of management without punishment (Dewi and Tanjung, 2007), organizational decision making (Ismail and Ibrahim, 2007), corporate governance (Amer, 2007; Mat and Ismail, 2007; Dusuki, 2007), quality management (Youssef and Al-Buraey, 2007), administrative theory (Sharfuddin, 1987), enterprise design (Chatha, 2007), management style of some Prophets (Shirazi, 1988), management of non-profit organizations (Kadi, 2007), and managerial and business ethics (Beekun, 1996).

The review from the literature (Toor, 2007 and Saleh, 2007) illustrates that AIP has triggered discussions in many parts of the world resulting in works in diverse areas where scholars have tried to view various disciplines from Islamic viewpoint. Although literature on Islamic perspective is just beginning to explore various dimensions of accounting, there is an obvious promise in the attempts made so far. Frameworks, constructs, theories, and proposals related to AIP are all in a very nascent form with enthusiastic future research plans by their proponents. However, before the research on AIP has gained full momentum, the pioneers of the field need to take a pause and discuss the issues that can have long-term repercussions on the field.

\section{Religious (Cultural) Based Accounting}

Japan that has a strong commitment to its traditional culture has a strong ability to formulate, to implement, its own accounting philosophy and principles difference from that of capitalistic society. Shinto for example has a potential drive to establish a Shinto based Accounting.

\section{Developing AIP as A Formal Discipline}

Scholars have emphasized on development of management in Islamic perspective as a formal academic discipline (Ismail, 2007). However, this aspiration needs in-depth analysis and pragmatic considerations. There are many questions that the researchers in this area will have to address while taking up this task. The following section elaborates on the challenges that are likely to emerge while developing AIP as a formal discipline.

\section{Defining AIP}

'Islamic accounting' as an emerging discipline, which deals with the financial reporting of organizations from the perspective of the 
knowledge acquired from the revealed and other Islamic sources of knowledge, and results in applications compatible with the Islamic beliefs and practices. Of course, the aims, objectives, operational activities and results of 'Islamic accounting' are determined according to Islamic Aaqida’ and Shari’ah.

Christopher Napier christopher.napier@rhul.ac.uk, Royal Holloway, University of London, note that the emergence of Islamic banks and other financial institutions since the 1970s has stimulated a modern literature that has identified itself as addressing "Islamic accounting". Much of this literature is prescriptive, though studies of actual practice, and of attitudes to proposed alternatives, are beginning to emerge. Historical research into Islamic accounting is still in a process of development, with a range of studies based on both primary archives and manuals of accounting providing growing insight into accounting in state and private contexts in the Middle East. Other parts of the Muslim world are also the focus of historical accounting research. There is still much to discover, however, before historians can determine the influence of Middle Eastern accounting ideas and practices in other parts of the world. Moreover, the term "Islamic accounting" may simply be a convenient label to group together quite disparate accounting practices and ideas across time and space.

According to Hayashi 'Islamic Accounting' (1989), “is an integrated discipline with social, political and economic domain ruled by Allah or "meta rule". Islamic accounting should regulate and establish a harmonious integration among the parties of these diverse domain". Hayashi continues that the Islamic accounting which has implicit economic, political and religious meaning (an integrated world view system, author), has the possibility to show the key to a post Newtonian Accounting (Western Secular based accounting, author)”.

Islamic accounting is generally defined as an alternative accounting system, which aims to provide users with information enabling them to operate businesses and organizations according to Shariah, or Islamic law. .........With little doubt, the greatest challenges to Islamic accounting and finance in the new world stem from a lack of knowledge and understanding of Islam and the intricacies of its financial laws. (October 5, 2006 http://www.accountingweb.com/cgibin/item.cgi?id=102651,) Dr. Shahul Hameed bin Mohamed Ibrahim says in http://islamic-finance.net/islamic-accounting/, both conventional and Islamic accounting provides information and define 
how that information is measured, valued, recorded and communicated. Conventional accounting provides information about economic events and transactions, measuring resources in terms of assets and liabilities, and communicating that information through financial statements users, typically investors, rely on to make decisions regarding their investments. Islamic accounting, however, identifies socioeconomic events and transactions measured in both financial and non-financial terms and the information is used to ensure Islamic organizations of all types adhere to Shariah and achieve the socio-economic objectives promoted by Islam. This is not to say, or imply, Islamic accounting is not concerned with money, and rather it is not concerned only with money.

The purpose of shariah (Islamic law) is to promote the welfare of the people which lies on: Safeguarding of their faith; their life; their intellect; their posterity and their Wealth. (Al- Gazali: 1058-1111)

Islamic accounting, in many ways, is more holistic. Shariah prohibits interest-based income or usury and also gambling, so part of what Islamic accounting does is help ensure companies do not harm others while making money and achieve an equitable allocation and distribution of wealth, not just among shareholders of a specific corporation but also among society in general. Of course, as with conventional accounting, this is not always achieved in practice, as an examination of the wide variances in wealth among the populations of Arab nations, particularly those with majority Muslim populations shows. In addition, because a significant part of operating within Shariah means delivering on Islam's socio-economic objectives, Islamic organizations have far wider interests and engage in more diverse activities than their non-Islamic counterparts.

Researchers exploring various sub-disciplines of AIP do attempt to define the key terms in sub-disciplines-such as Ownership, Debt Contract and Accounting, Trusteeship of Mankind, Inequality Natural, Record Book - Audit, Meeting Account, Verification of Information, Fulfill Contract, Full Measure and Weight in Just, Dealing in Fraud who give less in measure, quality management, corporate governance-it seems as if no deliberate attempt has been made to formally define AIP.

Most researchers seem to have added the word "Islam" or "Islamic perspective" with the conventional definitions of accounting, which itself 
seems to have been defined in several different ways and has no 'agreedupon' definition. Nevertheless, since AIP is just beginning to emerge, it seems plausible to have formal and agreed-upon definition of AIP to achieve coherence in ideas and to direct the efforts in one direction.

In view of Cooper et al., (2005, pp. 478), "a refined definition must include a specification of the nature of the dimension (e.g., trait, behavior, attribution, etc.), the observer/perspective of the persons(s) providing the report (e.g., self, subordinate, peer, etc.), the level(s) of analysis involved (e.g., individual, dyad, group, organization, etc.), the response category measurement units to be employed (e.g., frequency, magnitude, extent of agreement, etc.), and the dimension's content domain (including whether there are sub-dimensions involved)." In order to establish a formal definition of AIP, researchers will need to specify full set of dimensions, underlying concept, and sub-divisions of AIP. For this purpose, use of qualitative procedures is recommended. Such approaches include case studies of the organizations that claim to be implementing Islamic ways of accounting and interviews of practitioners, entrepreneurs, leaders, and managers, who appear to be following more Islamic approach of accounting. Input of Muslim religious scholars and accounting experts can also provide useful insights to develop and sharpen the definition of AIP.

\section{Islamic Accounting Web - (http://www.iiu.edu.my/iaw/)}

The Islamic Accounting Website is a project of the Department of Accounting, Kulliyah of Economics and Management Sciences, International Islamic University Malaysia, Kuala Lumpur. This project is under the direction of Dr. Shahul Hameed bin Mohamed Ibrahim, Assistant Professor and the current Head of the Department. The philosophy of the University is to Islamize knowledge to solve the crisis in Muslim thinking brought about by the secularization of knowledge and furthermore contributing as a centre of educational excellence to revive the dynamism of the Muslim Ummah in knowledge, learning and the professions. The Department of Accounting is fully committed to this vision and strives to Islamise Accounting.

\section{Bases of Islamic Accounting: Al Quran}

Islamic accounting can be defined as the "accounting process" which provides appropriate information (not necessarily limited to financial data) to stakeholders of an entity which will enable them to ensure that the entity is continuously operating within the bounds of the Islamic Shari'ah and delivering on its socioeconomic objectives. Islamic 
accounting is also a tool, which enables Muslims to evaluate their own accountabilities to Allah (in respect of interhuman/ environmental transactions).

\section{A. Ownership}

To Him belongs what is in the heavens and on earth, and all between them, and all beneath the soil.

(Surah Ta- Ha:6)

\section{B. Debt Contract and Accounting}

"O ye who believe! When ye deal with each other, in transactions involving future obligations in a fixed period of time, reduce them to writing let a scribe write down faithfully as between the parties; let not the scribe refuse to write: as Allah has taught him, so let him write. Let him who incurs the liability dictate, but let him fear his Lord Allah, and not diminish aught of what he owes. If the party liable is mentally deficient, or weak or unable himself to dictate, let his guardian dictate faithfully. And get two witnesses, out of your own men, and if there are not two men, then a man and two women, such as ye choose, for witnesses, so that if one of them errs, the other can remind her. The witnesses should not refuse when they are called on (for evidence). Disdain not to reduce to writing (your contract) for a future period, whether it be small or big: it is juster in the sight of Allah, more suitable as evidence, and more convenient to prevent doubts among yourselves but if it be a transaction which ye carry out on the spot among yourselves there is no blame on you if ye reduce it not to writing. But take witnesses whenever ye make a commercial contract; and let neither scribe nor witness suffer harm. If ye do (such harm), it would be wickedness in you. So fear Allah; for it is Allah that teaches you. And Allah is well acquainted with all things.” $\quad$ (Surah Al-Baqarah:282)

\section{Trusteeship of Mankind}

Behold, thy Lord said to the angels: "I will create a vicegerent on earth." They said: "Wilt Thou place therein one who will make mischief therein and shed blood? Whilst we do celebrate Thy praise and glorify Thy holy (name)?" He said: "I know what ye know not." 


\section{Inequality - Natural}

And it is He Who hath made you (His) agents, inheritors of the earth: He hath raised you in ranks, some above others: that He may try you in the gifts He hath given you: for thy Lord is quick in punishment: yet He is indeed Oft- Forgiving, Most Merciful. (Surah Al-An'am:165)

\section{E. Record Book - Audit}

Then he who is given his Record in his right hand, Soon will his account be taken by an easy reckoning, And he will turn to his people, rejoicing!, But he who is given his Record behind his back, Soon will he cry for Perdition, And he will enter a Blazing Fire.

\section{F. Meeting Account}

(Surah Al-Inshiqaq:7-12)

Then he that will be given his Record in his right hand will say: "Ah here! Read ye my Record!, "I did really understand that my Account would (one Day) reach me!”.

(Surah Al-Haqqah:19-20)

\section{G. Don't Mix Truth with Falsehood}

And cover not Truth with falsehood, nor conceal the Truth when ye know (what it is).

(Surah Al-Baqarah:42)

But verily it is Truth of assured certainty.

(Surah Al-Haqqah:51)

\section{H. Verification of Information}

O ye who believe! if a wicked person comes to you with any news, ascertain the truth, lest ye harm people unwittingly, and afterwards become full of repentance for what ye have done. (Surah Al-Hujurat:6)

\section{Fulfil Contract}

Come not nigh to the orphan's property except to improve it, until he attains the age of full strength; and fulfil (every) engagement, for (every) engagement, will be enquired into (on the Day of Reckoning).

(Surah Al-Isra:34)

\section{J. Full Measure and Weight in Just}

Give full measure when ye measure, and weigh with a balance that is straight; that is the most fitting and the most advantageous in the final determination.

(Surah Al-Isra:35)

\section{K. Dealing in Fraud Who Give Less in Measure}

Woe to those that deal in fraud, Those who, when they have to receive by measure, from men, exact full measure, But when they have to give by measure or weight to men, give less than due. Do they not think 
that they will be called to account ? On a Mighty Day, A Day when (all) mankind will stand before the Lord of the Worlds ? Nay! Surely the Record of the Wicked is (preserved) in Sijjin. And what will explain to thee what Sijjin is? (There is) a Register (fully) inscribed.

(Surah Al-Mutaffifin:1-9)

\section{Which is Left by ALLAH is Better}

To the Madyan people (We sent) Shu'aib, one of their own brethren: he said: "O my people! Worship Allah: ye have no other god but Him. And give not short measure or weight: I see you in prosperity, but I fear for you the Penalty of a Day that will compass (you) all round. "And O my people! give just measure and weight, nor withhold from the people the things that are their due: commit not evil in the land with intent to do mischief. "That which is left you by Allah is best for you, if ye (but) believed! but I am not set over you to keep watch!”

(Surah Hud:84-86)

\section{Distinguishing AIP from Conventional Accounting}

After researchers have defined and sharpened the definition of AIP, they will need to take a clear and elaborate stance as to how AIP differs from conventional accounting or emerging forms of accounting, which drive their inspiration from spirituality and servant leadership. If they are not able to distinguish AIP from existing and other emerging forms of accounting, this would imply that it is either equivalent to the conventional accounting with add-on of spirituality or a simply redundant concept. Researchers will also need to identify and focus on the points of divergence and accentuate these in their conceptualization and measurement of AIP. Though some scholars have already given some attention to the issue arguing that conventional accounting and AIP are distinct, there are many who note both similarities. For example, Loqman and Bulbul (2007) note that the 14 principles of conventional management given by Henri Fayol; are alike the principles of Islamic Management.

Some assertions, however, show that Islamic perspective offers distinct way of accounting. Loqman and Bulbul (2007) call these points of distinctions as additional principles of management. These include: khilafa (vicegerency), honesty, truthfulness, promise keeping, moderation, sincerity, timeliness, efficiency, patriotism, exemption, accountability in this world as well as in the life hereafter and more over Tawakkul (depending upon Allah SWT). These principles are not present in the conventional accounting approaches and therefore make 
AIP a unique perspective. Toor (2007) joins this stance and argues that Islam provides "extra dimensions" that are likely to enhance the positive nature of Islamic leadership. The most important "extra dimensions" in this regard include: surrendering to Allah SWT, trusteeship of Allah SWT, accountability to Allah SWT, obedience of Allah SWT and the Prophet, following the Shariah, virtuosity, mercy, forgiveness, compassion, social justice and consideration, service of mankind, righteousness, humility, positive firmness, inner struggle against the self, honesty, truthfulness, and positive organizational scholarship (hope, optimism, self-efficacy, and resiliency) from Islamic viewpoint. It also argues that Islamic accounting seems to differ on the worldview of accounting, its concepts and issues. They further note that Islamization of accounting is basically the need for a tauhidik approach based on social justice, fairness in managing people, and to seek the will of Allah SWT.

Despite these claims, there is a further need to distinguish how AIP differs from existing forms of accounting. This distinction will not only have an favorable impact on furthering the research on AIP, but it will also help in making a better understanding of the work that has already been done in the field. Distinguishing AIP from existing forms of accounting will also help to send the message across that AIP offers something unique and extra, and that the organizations can develop a sustainable competitive advantage from this something unique and extra. On a practical level, any misunderstanding or confusion of AIP with conventional accounting might hinder the development of AIP as a discipline. If researchers argue that AIP is a new discipline and is substantially different from the conventional accounting, clear lines of boundaries need to be drawn as to how both fields differ, although they may complement each other in many ways. These boundaries need to be drawn beyond definitional differences, by including conceptual distinctions, and functional divergence between conventional accounting and AIP. Such discussions can also address behavioral differences between a conventional accountant or and an AIP-accountant.

\section{Measuring AIP}

This is probably the biggest challenge that will confront the proponents of AIP. Current body of knowledge on AIP bases itself on integration of spirituality and religiosity within accounting practices. However, in the mainstream, there remains a debate on whether spirituality and religiosity represent one construct or they are two different constructs that cannot be combined together. There have been claims that 
religiosity is a very complex construct and is extremely hard to measure (Hashim, 2007, Muhamad, 2007), though some researcher have attempted to develop and validate such measures. Researchers have similar views about spirituality that it is complex and hard to measure (see: Fry, 2003; Fry et al., 2005; Dent Barrett, 2003; Ashmos \& Duchon, 2000; MacDonald et al., 199; Elkins et al., 1988).

However, all such measures of religiosity and spirituality have been established outside the Muslim world. Therefore, researchers will need to establish measures of religiosity and spirituality from Islamic perspective. As researchers of AIP currently argue that it is an integration of spirituality and religiosity, they will need to establish valid measures through which AIP can be assessed. For this purpose, it is important that two separate standardized quantitative measures are developed to assess AIP in the financial reporting. For this purpose, extensive labor and collaborative projects will have to be designed to develop and validate these measures across different cultures. Researchers will need to begin the work using qualitative approaches to eventually arrive at quantitative measures.

\section{Regulatory Issues}

The regulatory environment, Islamic individuals and organizations are most concerned with, considering the current political climate, are those relating to anti-terrorism and antimoney laundering. Yet the tensions arising from regulatory requirements within the American business practices often prove more difficult to resolve.

It is in trying to balance the expectations of distinct business cultures that the differences between conventional and Islamic accounting are most notable. For instance, depending upon the type of transactions the organizations are engaged in, the roles, responsibilities and rights assigned to each party can be contradictory and even in direct conflict. In some situations, such as transactions involving private equity, venture capital, profit sharing and liquidations, organizations and individuals employing conventional accounting may actually find they prefer Islamic accounting. Other issues, such as those related to taxation, require significant effort to resolve. The inherent flexibility of Shariah is a benefit under these circumstances, since the complexity of the contemporary tax code is highly inflexible.

Although demand for Islamic financial products and services has increased, both the supply and the number of providers remain 
insufficient. It should also be noted that Islamic orthodoxy, expressed as the desire to implement Shariah as the sole legal foundation of a nation, is actually associated with progressive economic principles, including increasing government for the poor, reducing income inequality and increasing government ownership of industries and industries, especially in the poorer nations of the Muslim world. While it is common to associate traditional religious beliefs with conservative political stances on a wide range of issues, this is only partly true, said Robert V. Robinson, Chancellor, Professor and chair of Indiana University.

\section{Implementing AIP in Practice}

Any discipline in the making is not a smooth path to walk on. The next challenge is to first sell and then implement and further develop the AIP practices in organizations. This will need a fundamental shift in accounting in many organizations; as it will depend upon the preparedness and capability of the organizations to accept an entirely new system, and quickly shift to AIP practices. How this shift of accounting can be smoothened and how desired results can be obtained is another question that needs to be addressed. For this purpose, case studies can be conducted on the organizations that claim to be, or are reputed as, close to AIP in terms of their management systems. Some examples of such studies in the existing literature include works of Mohiudding and Amin (2007) and Barhem and Muhamad (2007).

In their exploratory study in Bangladesh, Sobhani and Ather (2007) ascertain a number of factors that are perceived as causing the lack of awareness about management in Islamic perspective. These include: lack of knowledge on Islamic management; effects of western education and culture; lack of true practicing Muslims; lack of research on Islamic management; absence of Islamic environment \& culture; effects of globalization; effects of secular NGOs; lack of teaching \& practices of Holy Qur'an and Hadith; environmental bottlenecks; lack of institutional support; and lack of media coverage of Islamic management issues.

In order to make AIP as a principal way of management in Islamic societies, there is a need for a macro-scale movement. AIP would not be able to find its sterling routes unless there is supportive societal and organizational context. Its practices would not be implemented with the will of a single person but with readiness of everyone in the system. Sobhani and Ather's (2007) study highlights the issues in their order of preference that need to be addressed to solve the problems of awareness include: Islamization of knowledge and 
education; creating public consensus; reformation of the Government; adjustment of globalization with Islamic values and norms; putting restriction of NGOs, Islamizing educational models and procedures; removing corruption; establishment of Islamic accounting research centers; formulating rules and regulations for following Islamic values and norms; establishing Shari'ah based accountability, administration and communicating Islamic accounting through media. These recommendations provide useful insights for policy makers in the Islamic countries to seriously look into the issues and formulate adequate strategies so that Islamic societies can benefit from AIP.

It will be relatively easy to convince Muslims about the inherent benefits and implications of AIP. However, task will be much harder in non-Islamic lands. Therefore, in order to promote AIP as a viable alternative for the organizations, the researchers will need to present it as a source of competitive advantage so that organizations in both Islamic and non- Islamic countries can seriously consider it as an alternative management system. The will need to highlight why and how AIP is highly unique, more sustainable, long-term, hard to imitate, cumulative, valuable, and non-substitutable source of competitive advantage. They will also need to provide empirical evidence to demonstrate the validity of their claims. Perhaps a long way to go, but researchers of AIP will come across these challenges one by one. Thinking about these challenges in this very beginning is likely to result in formulation of a comprehensive long-term strategy to build AIP as a competitive and sustainable discipline.

\section{Researching AIP}

From methodological point of view, the researchers of AIP will need to consider which methodologies are suitable for research. The choice of research methods is most often shaped by aims, epistemological concerns, and norms of practice, as well as organizational, historical, political, ethical, evidential, and personal factors, typically treated as problems to be overcome (Buchanan and Bryman, 2007). In addition to the nature of research question, Bryman (2007) claims that other reasons such as disciplinary requirements-what should pass as acceptable knowledge, policy issues-expectations concerning the kind of knowledge they require for policy, and funding expectations of funding bodies also play a role in choosing the research methodology. Yet another possibility is personal interests, preferences, biases, prejudices, and creativity in addition to technical skills, knowledge, and competence of the researcher to conduct a particular kind of research. 
Current research on accounting is dominated by positivist or quantitative approaches. Quantitative research methods are characterized by the assumption that human behavior can be explained by social facts. Such research methodologies employ the deductive logic of the natural sciences. Quantitative methods were vastly used for accounting studies during 1960s and 1970s. Proponents of qualitative research argue that it allows richer descriptions, sensitivity of ideas and meanings of the individual concerned, increased likelihood of developing empirically supported new ideas with practical relevance and increased interest of practitioners (Martin and Turner, 1986). Qualitative approaches also help in discovering new ideas and phenomena rather than verifying the old and existing theories (Bryman, 1984).

Bryman (1984) suggests linking of more abstract philosophical issues with questions of research practice. He thinks that it is a better and sophisticated way of treating the comparability of different methods of investigation than direct juxtaposition in terms of relative superiority. Rocco et al. (2003) argue that 'mixing methods that bring together the strengths of both quantitative and qualitative methods will enhance research in the field' (Rocco et al., 2003, p. 604).

However, AIP being a discipline in-making needs to establish its epistemological grounds and constructs in the beginning, which can then be tested and validated at a later stage. Therefore, it seems to the current author that the researchers need to use all quantitative, qualitative, and mixed-method approach with maximum methodological inventiveness.

According to Buchanan and Bryman (2007), organization research is a meeting point for numerous disciplines including psychology, social psychology, sociology, economics, public policy, history, anthropology, and the business areas of strategy, finance, marketing, human resources, and operations management. Research on AIP will also see integration and interplay of many disciplines with in its scope. Therefore, a debate on methodological issues to research AIP can be beneficial in the beginning to choose appropriate research methodologies. This will help the researchers to avoid any methodological dilemmas at a later stage that might otherwise result in another war or paradigms. Furthermore, while conducting research on AIP, the researchers will need to consider the intertwining effect of local cultures and norms in different countries around the world. 
Current debate in accounting research has repeatedly highlighted the crosscultural issues and alerted about the cultural consequences. Measurements and conceptual issues related to AIP will be most crucial in cross-cultural setting.

\section{Priority Areas of Focus}

Recent attempts of research from the perspective of AIP seem to be highlighting issues such as Ownership, Debt Contract and Accounting, Trusteeship of Mankind, Inequality - Natural, Record Book- Audit, Meeting Account, Verification of Information, Fulfill Contract, Full Measure and Weight in Just, Dealing in Fraud who give less in measure,, corporate governance, and quality management. Existing research on AIP also appears to be without an explicit intention to develop constructs, theories, and frameworks that can lead to development of a comprehensive "Theory of Accounting from Islamic Perspectives". In order to establish AIP and its sub disciplines, it is important that organized efforts are undertaken instead of randomly choosing the areas for research under AIP. Body of knowledge on conventional accounting has developed organically over almost a hundred years. Even today, many more disciplines continue to emerge and attract the attention of scholars. However, researchers of AIP will have to prioritize the knowledge areas they would like to focus in the beginning, until the field is relatively established, and there is substantial number of qualified and established academics extensively working in the field. If AIP research continues to grow organically and at random choices of sub-disciplines, there is likelihood that many researchers will be distracted or they will duplicate each other's efforts or will simply explore the areas, which do not contribute to a coherent effort of developing AIP as a discipline.

There is also a possibility that research efforts on AIP in different parts of the world are totally unaware of each other, and they lose the opportunity of mutual sharing and complementing of the ideas and perspectives of the subject. Therefore, proponents of AIP will need to organize the efforts and more importantly prioritize what they want to research, and the beginning, and what sub-discipline would then be explored after constructs on the prioritized themes have been well established. Only then the lessons learnt from the initial phase of the research can be taken forward to address other issues that need to be investigated at later stages. Few initial sub-disciplines that can be explored in the beginning can include, but not limited to, Ownership, Debt Contract and Accounting, Trusteeship of Mankind, Inequality - 
Natural, Record Book - Audit, Meeting Account, Verification of Information, Fulfill Contract, Full Measure and Weight in Just, Dealing in Fraud who give less in measure, corporate governance, and accounting ethics. In order to develop and grow these sub-disciplines, researchers will need to assemble the existing body of knowledge, write inclusive literature reviews, conduct dialogues and debates, and finally, establish research agendas as to how to approach these disciplines from Islamic perspectives. Further sub-disciplines can then be explored in the pipeline.

\section{Potential Opportunities}

There are a number of steps that need to be taken while establishing AIP as a formal academic discipline, and produce a useful and rigorous research on the subject. Preceding sections discuss in detail the achievements that have been made in the context of AIP. The author has also highlighted multitude of challenges that face AIP research and development. In the midst of these challenges, however, there lie numerous opportunities. It is a very timely prospect for scholars in the Islamic world to make use of those opportunities. They can come up front and contribute their efforts for developing and flourishing the field. However, their efforts need to be well planned, systematically organized, thoroughly contemplated, and more importantly pragmatic.

Since much needs to be accomplished in this regard, the author proposes the formulation of an international consortium on AIP, comprising the established researchers in Islamic studies, accounting, basic sciences, sociology, anthropology, statistics, and other relevant discipline to formulate and drive an organized research effort on AIP. The consortium can establish the priority themes for research, develop a detailed research agenda, and decide methodologies can establish the priority themes for research, develop a detailed research agenda, and decide methodologies to be used. To effectively divide the tasks, such consortium can establish various task groups and working commissions of sub-disciplines of AIP.

These research groups can then pursue their own agenda under the guidelines of consortium. Approaching the task in this manner would decrease the burden of this undertaking falling on only one group. This will also ensure that there is no duplication of research endeavors by various researchers of AIP around the world. 
Such consortium can also organize an annual congress where debates and dialogues can be invited to share the knowledge. From different disciplines, share the achievements that are made by various research groups, and plan the future goals in accordance. Independent and joint conferences and symposia of research groups can also facilitate the knowledge sharing process. Dialogues and knowledge exchanges between experts of AIP and conventional accounting should also be a part of this overall endeavor so that AIP can gradually become a mainstream discipline to benefit the entire world, be it Muslims or non-Muslims. Organizing such activities in different parts of the world will also help to spread the awareness about AIP within and beyond the Islamic countries. The consortium can also extend its efforts to issue literary journals and magazines to share the research achievements. Additionally, the consortium can also think to establish research centers in various Islamic countries to consolidate and streamline the research process. The forum can be either established independently or under the research arm of an already existing international organization such as Organization of Islamic Countries (OIC). This will not only be helpful in drawing capable researcher from around the word but will also be useful in rapidly establishing the credibility of the research that stems from the consortium efforts. Such large-scale consortium-based effort will also be helpful in drawing funds that will be required for developing AIP. Given the soaring interest in Islamic Banking, Islamic Finance, and Shariah Compliance, the author is hopeful that industry funding can be attracted for research on AIP. Various governments can also be instrumental in driving this undertaking by allocating research funds.

As a part of this whole effort, universities across the Islamic countries can also offer joint courses on both Islamic Studies as well as Accounting to establish and grow the discipline of AIP. These research endeavors can then be closely observed by the above consortium, which can act as an overall accrediting body for such academic efforts. Although some universities are pioneering such efforts by offering such courses-for example, Bachelor of Islamic Finance and Banking (BIFB, Hons) at University Utara Malaysia-these courses are at undergraduate level. More efforts at graduate level need to be undertaken. AIA joins forces with BIBF to launch diploma in Islamic Accounting and Compliance. The Association of International Accountants (AIA) has joined forces with the Bahrain Institute of Banking and Finance (BIBF) to officially launch its Diploma in Islamic Accounting and Compliance at the World Islamic Funds and 
Capital Markets Conference to be held in Bahrain on 26 and 27 May 2008. AIA Chief Executive attends Bahrain conference to officially launch new joint BIBF Diploma in Islamic Accounting and Compliance. Aimed at employers, the new qualification provides a thorough understanding of the Islamic Accounting and Governance Reporting requirements as set by the Accounting and Auditing Organization for Islamic Financial Institutions (AAOIFI) and a comparison with International Financial Reporting Standards (IFRS). The graduates of the AIA and BIBF Diploma in Islamic Accounting and Compliance (DIAC) will enable Islamic financial institutions to access global markets while maintaining the substantial processes and forms of Islamic transactions.

$\mathrm{PhD}$ research projects and postdoctoral fellowships can be instrumental to accelerate the research output and to establish various sub-disciplines. Given the current drive in AIP research, it carries a significant potential to grow as a formal discipline. However, this aspiration can be materialized more effectively and efficiently, if researchers of AIP join their hands for a larger collaborative research endeavors instead of disintegrated and fragmented attempts, which can considerably slow the momentum that can otherwise be achieved.

\section{IFRS for Merger of Islamic Accounting Standards}

According to Karen Remo-Listana (2009), the proponent of the International Financial Reporting Standards (IFRS) will be in talks with Islamic finance authorities this year and will be ready to modify the existing system to accommodate Islamic finance standards.

According to Robert Garnett (2009), board member of International Accounting Standards Board (IASB), there may be "slight differences" but they can be resolved through critical judgment. "We have to embrace all financial products so we will need to change our standards," Garnett told Emirates Business on the sidelines of the IFRS breakfast briefing in Dubai. "To converge with Islamic finance standards we need to have some detailed discussions with AAOIFI (Accounting and Auditing Organisation for Islamic Financial Institutions) so we can have a better understanding of their concerns and how we can accommodate those within a revised IFRS," he added.

\section{Concluding Remarks}

Accounting from Islamic perspectives (AIP) is a nascent discipline with a considerable promise. The extant body of knowledge is largely 
fragmented and research efforts are apparently disorganized in reference with AIP. In order to develop AIP as a formal and accepted discipline, there are both challenges and opportunities that lie ached. To ensure a healthy growth and expansion of the discipline, researchers of AIP will need to integrate and streamline their efforts to ensure that there is a constructive growth of knowledge in the discipline before any significant split or divergence of focus can find its roots. This paper presents a summary of literary achievements that have been so far made in the field of AIP. It also lists and discusses the challenges and opportunities that proponents of AIP will confront in the future. A proposal for an international consortium has been briefly presented to conduct organized research and establish AIP as a mainstream discipline, which can benefit the whole world. After a long halt of research in the Islamic world, there seems some light in the end of the tunnel. It provides an historic opportunity for the scholars to revive and contribute to the grand tradition of knowledge generation and sharing that Islam encourages. It also provides an impetus for scholars in all other disciplines to start thinking about how, as Muslims, we can contribute to the well being of humanity.

\section{References}

1. AAA(1966), A Statement of Basic Accounting Theory, US: American Accounting Association.

2. Abuznaid, S. (2006). Islam and Management: What Can Be Learned? Thunderbird International Business Review, 48: 125-139.

3. Ahmed, S.A. (2007). Interjecting the Core Islamic Values for Raising the Employee's Behavior. Proceeding of the International Conference on Management from Islamic Perspectives (ICMIP), May 15-16, Kuala Lumpur, Malaysia.

4. Al-Buraey, Muhammad A. (2003). Management and Administration in Islam. Bangalore, India: Iqua Welfare Publications.

5. Al-Quran

6. Amer, S. (2007). Corporate Governance from an Islamic Perspective. Proceeding of the International Conference on Management from Islamic Perspectives (ICMIP), May 15-16, Kuala Lumpur, Malaysia.

7. Amin, M.R. (2007). Motivating People in Organizations: The Islamic Way. Proceeding of the International Conference on Management from Islamic Perspectives (ICMIP), May 15-16, Kuala Lumpur, Malaysia.

8. Ashmos, D., and Duchon, D. (2000). Spirituality at Work: A Conceptualization and Measure. Journal of Management Inquiry, 9(2)., 134-145. 
9. Ata al- Sid, M. (2007). Contemporary Attempts at Overcoming Decadence and Revitalizing Qur'anic Thought. Business Review 2(1): 56-75.

10. Ata-ur-Rahman and Nassim, A. (2004). Time for enlightened moderation: A call for Islamic nations to renew and reaffirm their commitment to science. Nature, Vol. 432, pp. 273-274.

11. Ather, S.M. (2005). Islamic Management and Business, International Islamic University, Chittagong, Bangladesh.

12. Bani-Sadr, A. (1980). Work and the worker in Islam. Tehran, Hamdani Foundations.

13. Barhem, B.Y.M. and Muhamad, R. (2007). Religiosity and Work Stress Coping Behavior among the Muslim Employees. Proceeding of the International Conference on Management from Islamic Perspectives (ICMIP), May 15-16, Kuala Lumpur, Malaysia.

14. Barrett, R. (2003). Culture and Consciousness: Measuring Spirituality in the workplace by mapping values. Handbook of workplace Spirituality and Organizational Performance. (pp. 345-366). New York: M. E. Sharp.

15. Beekum, R.I. (1996). Islamic Business Ethics, University of Nevada Islamic Training Foundation, November 01.

16. Beekum, R.I. (1997). Islamic Business Ethics, USA: The International Institute of Islamic Thought.

17. Beekum, R.I. and Badawi, J. (1999). Leadership: An Islamic Perspective, Herndon, VA: Amana Publications.

18. Beik, I.S. and Arsyianti, L.D. (2007). Islamic Paradigm on Leadership and Management: A Conceptual Analysis. Proceeding of the International Conference on Management from Islamic Perspectives (ICMIP), May 15-16, Kuala Lumpur, Malaysia.

19. Bryman, A (1984). The debate about quantitative and qualitative research: a question of method or epistemology. The British Journal of Sociology 35:1 76-92

20. Bryman, A. (2007). The Research Question in Social Research: What is its Role?, International Journal of Social Research Methodology, 10: 5- 20.

21. Buchanan, D. and Bryman, A. (2007). contextualizing methods choice in organizational research', Organizational Research Methods, 10: 483- 501

22. Cameron, K., Dutton, J.E., and Quinn, R.E. (2003). Positive Organizational Scholarship. San Francisco: Berrett-Koehler.

23. Chapra, M.U. (1992). Islam and the Economic Challenge. International Institute of Islamic Thought, Herndon, VA. USA.

24. Chapra, U (2000), The Future of Economics, An Islamic Perspective, Leicester, UK: The Islamic Foundation.

25. Chatha, K.A. (2007).Islamic perspective to enterprise design. Proceeding of the International Conference on Management from Islamic Perspectives (ICMIP). May 15-16, Kula Lumpur, Malaysia. 
26. Cooper, C.D., Scandura, T.A., and Schriesheim, C.A. (2005). Looking forward but learning from our past: Potential challenges to developing authentic leadership theory and authenic leaders. The Leadership Quarterly 16 (3): 475-493.

27. Dent, E.B, Higgins M.E. and Wharff, D. M. (2005). Spirituality and leadership: an empirical. review of definitions, distinctions, and embedded assumptions. the Leadership Quarterly 16: 625-653.

28. Dewi, M.K. And Tanjung, H. (2007) discipline without Punishment- Is it Possible? Proceeding of the International Conference on Management from Islamic Perspectives (ICMIP), May 15-16, Kula Lumpur, Malaysia.

29. Dusuki, A.W. (2007). The Application of Shariah Framework to stakeholder Management. Proceeeding of the International Conference on Management from Islamic Perspectives (ICMIP). May 15-16, Kula Lumpur, Malaysia.

30. Elkins, D., Hedstrom, L., Hughes, L., Leaf, J., and Saunders, C., (1988). Toward a humanistic- phenomenological spirituality: Definition, description, and measurement. Journal of Humanistic Psychology 28 (4): 5-18.

31. Ezzati, A. (1982) The concept of leadership in Islam. Al- Nahdah 2 (2): 24-29.

32. Faridi, F.r. (1995, Ed.). Islamic Principles of Business Organization and Management. New Delhi: Qazi Publishers and Distributors.

33. Fariduddin, M.(1987). Workers right in Islam. Bangladesh: Islamic Foundation.

34. FASB (1978), Statement of Financial Accounting Concept 1:Objectives of Financial Reporting by Business Enterprises, Stamford, Connecticut: Financial Accounting Standards Board.

35. Fontaine, R. (2007). Islamic Entrepreneurship: An Exploratory Study. Proceeding of the International conference on Management from Islamic Perspective (ICMIP), May 15-16, Kula Lumpur, Malaysia.

36. Fry L.W., Vitucci S., and Ceditllo, M. (2005). Transforming the Army through spiritual leadership. The Leadership Quarterly 16(5): 835-862.

37. Fry, L. W. (2003). Toward a theory of spiritual leadership. the Leadership Quaterly 14: 693-727.

38. Gahein. M. (1986). Marketing Strategies of Small Companies with particular reference to the Textile Industry in Egypt as an Islamic Developing Country. (Volumes 1 and 2), Unpublished Ph.D. Dissertation, University of Strathclyde, United Kingdom.

39. Goulding, C. (2003). Groundejd Theory: a Practical Guide for Management, Business and Market Researchers . Springer, Berlin.

40. Gray, RH, Owens K and Maunders K (1996), Accounting and Accountability: Changes and Challenges in Corporate Social and Environmental Accounting, London: Prentice Hall.

41. Hashim, J. (2007). Religion as a Determinant in Self- Directed Learning at the Workplace. Proceeding of the International Conference on Management from Islamic Perspectives (ICMIP), May 15-16, Kula Lumpur, Malaysia. 
42. Hicks, D.A. (2002) Spiritual and religious diversity in the workplace: implication for leadership. The Leadership quarterly 13: 379-96.

43. http://islamic-finance.net/islamic-accounting

44. http://www.accountingweb.com/cgi-bin/item.cgi?id=102651

45. Islam, M.Z. (2007). Accounting Philosophy Ethics and Principles- The Islamic Perspective, Bangladesh Institute of Islamic Thought, Dhaka.

46. Islmail, Y. (2007). A Proposed Approach to Development of Islamic Management as a Discipline. Proceeding of the International Conference on Management from Islamic Perspectives (ICMIP), May 15-16, Kula Lumpur, Malaysia.

47. Ismail, Y. and Sarif, S, M. (2007). the Coverage of Islamic Management Materials in the Interenet Search Engines. Proceeding of the International Conference on Management from Islamic Perspectives (ICMIP), May 15-16, Kula Lumpur, Malaysia.

48. Ismail, Y. Ibrahim, B.b.H. (2007). Leadership Preogatives and the Role of Advisors in Organizational Decision- Making. Proceeding of the International Conference on Management from Islamic Perspectives (ICMIP), May 15-16, Kula Lumpur, Malaysia.

49. Kadi, O. (2007). Managing Islamic Non- Profit Organization (INO).: the Islamic Perspective in North America. Proceeding of the International Conference on Management from Islamic Perspectives (ICMIP), May 15-16, Kula Lumpur, Malaysia.

50. Karen Remo-Listana (2007). Managing from Islamic Perspectives: Some Preliminary Findings from Malaysian Muslim- Managed Organizations. Proceeding of the International Conference on Management from Islamic Perspectives (ICMIP), May 15-16, Kula Lumpur, Malaysia.

51. Kazmi, A (2003). A proposed research agenda from Islamic perspectives to management studies. IIUM Journal of Economics and Management 11 (2): 197228.

52. Khalifa, a. s. (2001). Towards and Islamic Foundation of Strategic Business Management. Unpublished Ph.d. Dissertation, International Islamic University Malaysia, Kuala Lumpur, Malaysia.

53. Kriger, M. and Seng, Y. (2005) Leadership with inner meaning: A contingency theory of Leadership based on the wordlviews of five religions. The Leadership Quarterly 16: 771-806.

54. Loqman, $\mathrm{M}$ and bulbul, a. (2007). convergence and Divergence between Conventional Approach and Islamic Approach to Management. Proceeding of the International Conference on Management from Islamic Perspectives (ICMIP), May 15-16, Kula Lumpur, Malaysia.

55. MacDonald, D.A., Kuentzel, J.G., \& Friedman, H.L. (1999). A survey of measures of spiritual and transpersonal constructs: Part two- Additional instruments. The Journal of Transpersonal Psychology 31 (2): 155-177. 
56. Martin, P.Y. turner, B.A. (1986) Grounded theory and organizational research. Journal of Applied Behavioral Science 22: 141-157.

57. Mat, I. and Ismail, Y. (2007). Corporate Governance: A Theoretical Analysis of Triangular Relationships between the Shareholders, the board, and Chief Executive. Proceeding of the International Conference on Management from Islamic Perspectives (ICMIP), May 15-16, KulaLumpur, Malaysia.

58. Mohamed, N.S. (2007). Styles and Strategies of Motivation in Islamic Organizations. Proceeding of the International Conference on Management from Islamic Perspectives (ICMIP), May 15-16, Kula Lumpur, Malaysia.

59. Mohiuddin, M G. and Amin, M.R. (2007). Human Resource Management: An Islamic Perspective. Proceeding of the International Conference on Management from Islamic Perspectives (ICMIP), May 15-16, Kula Lumpur, Malaysia.

60. Mohiuddin, M.G. (2004). Islamic Management and its present application in Bangladesh. Unpublished Ph.D. Dissertation, Department of Management, Islamic University, Kushtia, Bangladesh.

61. Muhamad, R. (2007). A Study on the Influence of Education Stream and Religiosity on Ethical Awareness of Malay Muslim Students i Malaysia. Proceeding of the International Conference on Management from Islamic Perspectives (ICMIP), May 15-16, Kula Lumpur, Malaysia.

62. Nasr, S.H. (1961). Religion and Secularism. The Islamic Quarterly Review 6 (3): 124-125.

63. Noordin, M.F. and Othman, R. (2007). Islamic Management: A Citation Analysis. Proceeding of the International Conference on Management from Islamic Perspectives (ICMIP), May 15-16, Kula Lumpur, Malaysia.

64. Rae, S., and Wong, K., (1996). Beyond integrity: A Judeo- Christian approach to business ethics. Michgan: Zondervan Publishing House.

65. Rahman, M. and al- Buraey, M. (1992). An Islamic perspective of organizational controls and performance evaluation. The American Journal of Islamic Social Sciences 9 (4)

66. Randeree, K. (2007). Leadership Lessons for Contemporary Managers from Early Islamic Literature. Proceeding of the International Conference on Management from Islamic Perspectives (ICMIP), May 15-16, Kula Lumpur, Malaysia.

67. Robert Garnett (2009). Islamic Ethics and the Implications for Business. Journal of Business Ethics 18: 345-358.

68. Saleh, A. M. (2007). Leadership: An Islamic perspectie. Proceeding of the International Conference on Management from Islamic Perspectives (ICMIP), May 15-16, Kula Lumpur, Malaysia.

69. Schopper, H. (2006). Where are the new patrons of science? Islam and science, Nature 444 (2): 35-36.

70. Segal, A. (1996). Why does the Muslim world lag in science? the Middle East Quarterly 3 (2) 
71. Shahul Hameed (2001), "Islamic Accounting - Accounting for the New Millenium?”, Paper presented at the Asia Pacific Conference 1, Kota Bahru, Kelantan, October 10-12, 2001,

72. Sharfuddin, I. O.M. (1987), Towards an Islamic Administrative Theory. The American Journal of Islamic social Sciences 4(2):229-244.

73. Shirazi, AN.M. (1988). Management and Leadership in the Life of the Prophet (S)," al- Tawhid, 5 (2): 157-165.

74. Sobhani, F. A and Ather, S.M. (2007). Islamic Management in Bangladesh Status, Issues and Solutions. Proceeding of the International Conference on Management from Islamic Perspectives (ICMIP), May 15-16, Kula Lumpur, Malaysia.

75. Toor, S.r. (2007). An Islamic Leadership Theory: Exploring the Extra Dimensions. Proceeding of the International Conference on Management from Islamic Perspectives (ICMIP), May 15-16, Kula Lumpur, Malaysia.

76. Yom, S. L. (2002). Islam and Globalization: Secularism, Religion, and Radicalism.

77. Youssef, M.A. and Al- Buraey, M.A. (2007). From TQM to Quantum Quality: An Islamic Perspective. Proceeding of the International Conference on Management from Islamic Perspectives (ICMIP), May 15-16, Kula Lumpur, Malaysia 